\title{
A preliminary assessment of soil sulphur contamination and vegetations in the vicinity of former boreholes on the afforested post-mine site Jeziórko
}

\author{
Justyna Likus-Cieślik ${ }^{1}$, Marcin Pietrzykowski ${ }^{1}$, Martyna Śliwińska-Siuśta ${ }^{1}$, \\ Wojciech Krzaklewski ${ }^{1}$, Marta Szostak ${ }^{2}$ \\ ${ }^{1}$ University of Agriculture in Krakow, Faculty of Forestry, Institute of Forest Ecology and Silviculture, \\ Department of Forest Ecology and Reclamation; al. 29 Listopada 46, 31-425 Krakow, Poland \\ ${ }^{2}$ University of Agriculture in Krakow, Faculty of Forestry, Institute of Forest Resources Management, \\ Department of Forest Management, Geomatics and Forest Economics; al. 29 Listopada 46, 31-425 Krakow, Poland; \\ e-mail:j.likus@ur.krakow.pl,rlpietrz@cyf-kr.edu.pl
}

(C) 2015 Authors. This is an open access publication, which can be used, distributed and reproduced in any medium according to the Creative Commons CC-BY 4.0 License requiring that the original work has been properly cited.

Received: 3 December 2014; accepted: 26 September 2015

\begin{abstract}
The work aims to assess the degree of soil sulphur contamination of the various abandoned reclamation efficiencies, within the microhabitats formed in the "Jeziórko" inoperative boreholes of former sulphur-mining areas. These areas have been reclaimed to the forest. Three plot categories were initially determined in the post-mining areas: category $\mathrm{D}$ - degraded, i.e. ineffectively reclaimed and unsuccessfully afforested plots, with low cover-abundance or complete lack of vegetation, category $(\mathrm{P})$ - pine stands and category $(\mathrm{B})$ - birch stands successfully afforested. Afterwards, four circular plots were defined within each of the determined categories (4 replications, i.e. a total of 12 plots). For each plot, cover-abundance (according to the Braun-Blanquet scale) and dominant herbaceous vegetation species, tree species and stand density were determined. Height $(\mathrm{Ht})$ and diameter at breast height (DBH) measurements were taken, and a vitality assessment was completed, according to the IUFRO classification. Soil samples were collected at each plot, in five points, at two different depths $(0-5 \mathrm{~cm}$ and 5-40 cm). Finally, laboratory analysis was undertaken. Soil properties such as texture, $\mathrm{pH}$, electrical conductivity (EC), hydrolytic acidity (Hh), the contents of soil organic carbon SOC, total nitrogen TN, total sulphur TS, and exchangeable cations $\left(\mathrm{Ca}^{2+}, \mathrm{Mg}^{2+}, \mathrm{K}^{+}, \mathrm{Na}^{+}\right)$were determined. Soils from the $\mathrm{D}$ plot category were characterised by high sulphur contamination, excess salinity (EC) and strong acidity in top soil. These parameters indicated that completed neutralization was not performed effectively at certain sites. Pine $(\mathrm{P})$ and birch (B) stands categories showed good growth rates and soil parameters, indicating that the reclamation treatments were completed successfully.
\end{abstract}

Keywords: reclamation, afforestation, underground melting sulphur mine, pollution of sulphur

\section{INTRODUCTION}

A direct effect of excessive sulphur dioxide $\left(\mathrm{SO}_{2}\right)$ concentrations is the deterioration in the physiological state of the vegetation, including whitening and necrotic changes in foliage of woody species (Warmiński et al. 2005). Excessive sulphur concentrations also have an indirect adverse impact on soils, deteriorating their physicochemical and biological properties, resulting in nutrient leaching, as well as in the release of toxic metals, harmful to microbial organisms in the soil 
(Motowicka-Terelak \& Dudka 1991, Menz \& Seip 2004). The negative atmospheric $\mathrm{SO}_{2}$ impact on forests, both on the local and regional scales, has been documented since the 1950s (Härtel 1953).

Poland is abundant in economically viable sulphur deposits. The Tarnobrzeg (Fig. 1) sulphur deposit is one of the largest in the world (Pawłowski et al. 1985). Sulphur exploitation has been taking place there since 1961 (Gołda et al. 2005, Michno et al. 2009). Deeper buried parts of the native sulphur deposit were exploited by an underground melting and extraction process, applying the Frasch method. Melted, liquid-state sulphur was pumped to the surface (Warzybok 2000, Michno et al. 2009).

About 8000 boreholes were drilled within the Jeziórko mining field alone (Gołda et al. 2005). This mining technology had significant adverse consequences for the environment. Numerous liquid sulphur spills, resulting from technological failures within the boreholes and in the distribution systems, were particularly troublesome. Moreover, sulphur was spilled in an uncontrolled manner from the technological storage facilities (Michno et al. 2009). As a result, widespread tracts of difficult to reclaim sulphur-contaminated and excessively acidic soils were created. Post-mining areas also showed numerous geomechanical displacements, such as subsidence and hydrological changes, resulting in the rise of the water table and a reduction in the soil aerated layer thickness (Warzybok 2000, Gołda et al. 2005, Michno et al. 2009). Similar damage was observed in the Basznia and Nemiriv sulphur mines (Gąsiewicz et al. 2012). The most difficult problem in the reclamation processes was caused by chemical conversions that occurred point-wise within the post-mining borehole areas, in particular by those caused by technological failures and spills.

Despite the reclamation works conducted in the Jeziórko mining field during the 1993-2010 period, there are still minor patches of uncovered or poorly covered with vegetation areas transferred to the use of forestry. These areas correspond to the locations of former mining boreholes, post-eruption areas and technological waste storage sites. The full utility value of the soil could not be restored on these types of land, and the succession of vegetation has clearly halted. These areas constitute specific microbiotopes, as a result of the response of vegetation to unique habitat conditions in the mosaic of regenerating ecosystems.

The work aims to provide a preliminary description as well as assessment of the degree of soil sulphur contamination around the inoperative post-mining boreholes of the reclaimed Jeziórko sulphur mine sites.

\section{METHODS USED IN THE STUDY SITE}

The studies were carried out at reclaimed post-mining sites of the Jeziórko sulphur mine area, where reclamation began in 1993. Of the 2140 ha occupied for mining use, an area of 1179 ha was reclaimed by 2010, of which 705 ha was afforested land. An area of 374 ha was transferred under the management of the State Forests National Forest Holding, of which 332 ha were included in the district managed by Nowa Dęba Forest Inspectorate and 42 ha in that of Rozwadów Forest Inspectorate (Pietrzykowski et al. 2012).

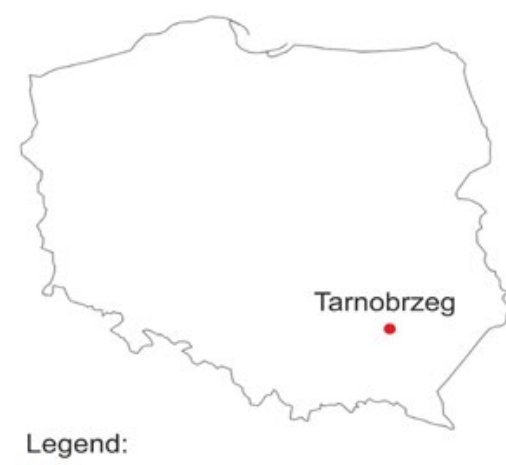

- location of area studied

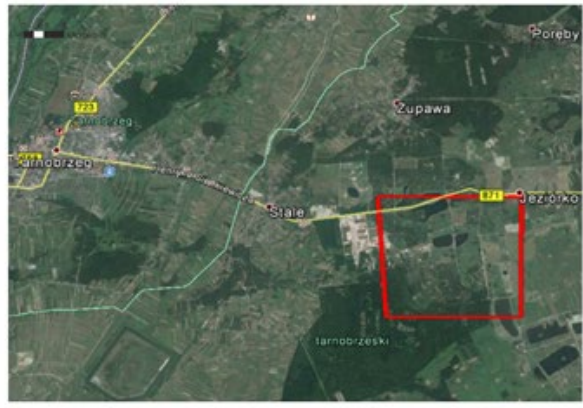

Legend:

$\square$ location of researched area Source: GoogleEarth

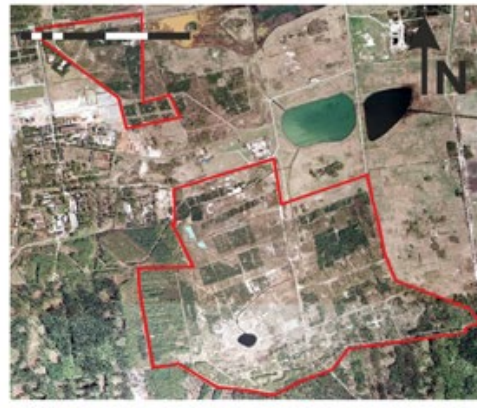

Legend:

- edge of reclaimed area

Source: CODGiK

Fig. 1. Location of area studied and general overview 
The area of study in which the fieldwork was completed is characterised by foothill plains and a valley climate, with an average annual temperature of $+8.2^{\circ} \mathrm{C}\left(-1.6^{\circ} \mathrm{C}\right.$ in January, $+18.7^{\circ} \mathrm{C}$ in July). Average annual precipitation is within the 550 to $650 \mathrm{~mm}$ range. The growing season lasts 200 to 220 days p.a. Snow cover occurs on average for 60 to 90 days p.a. (Woś 1999). Sandy soils, alluvial soils and locally peat soils originally prevailed in the areas eventually taken over by the Jeziórko sulphur mine (Pietrzykowski et al. 2012). The following forest habitats were chosen for the reclaimed areas: fresh mixed coniferous forest (BMśw in the Polish forest site classification system - Klasyfikacja gleb leśnych Polski 2000), fresh coniferous forest (Bśw) and mixed moist coniferous forests (BMw) (Plan Urządzenia Lasu dla Nadleśnictwa Nowa Dęba).

Study areas were located in the former sulphur mining areas (Fig. 2). The study plots were located based on different GPS measurements (Trimble
Pathfinder ProXRS receiver, base station of the University of Agriculture in Krakow; WGS84: $\left.50^{\circ} 04^{\prime} 59.07405 \mathrm{~N} ; 1^{\circ} 57^{\prime} 02.39439 \mathrm{E} ; 255.47 \mathrm{~m}\right)$. GPS data was also collected for preparing the photointerpretation key (geotagging photos). Following an initial assessment, inventory and determination of land cover classes (on-screen vectorization of an orthophotomap from 2009 - a $25 \mathrm{~cm}$ pixel), patches of microhabitats were chosen in three categories. The first included degraded plots (D), i.e. spaces characterised by low vegetation coverage with herbaceous plants from succession and tree stand, with probably the strongest surface contamination by melted sulphur eruptions (technological failures), or due to soil re-digging and exposure of mineral sulphur during borehole liquidation works. This category (degraded plots D) showed pellets of mineral sulphur formed even on the surface. Categories of land with Scots pine $(\mathrm{P})$ and land with birch (B) included successfully afforested land with homogeneous forest stands.

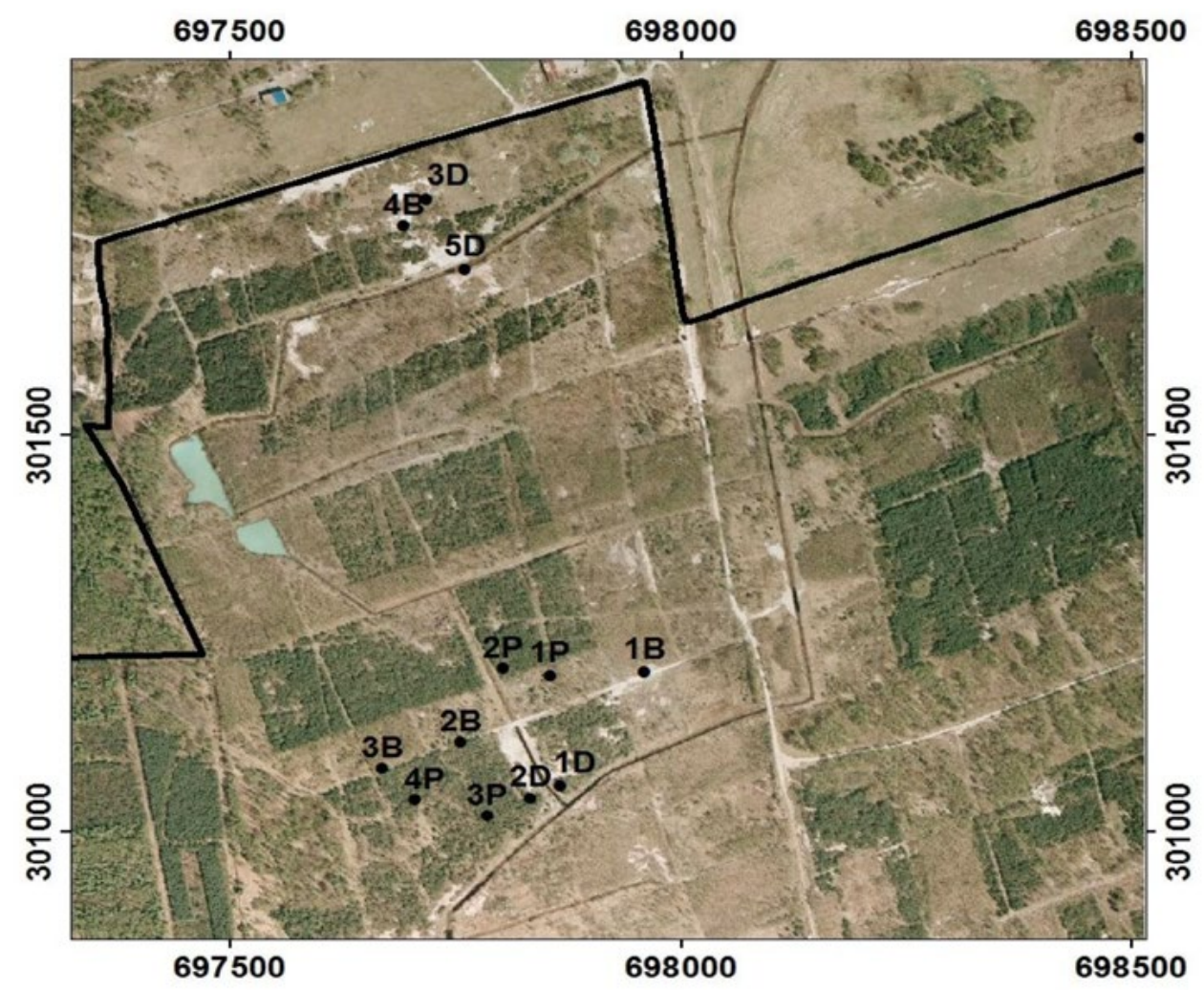

Legend:

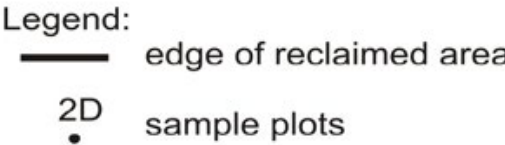

$1 \mathrm{D}, 2 \mathrm{D}, 3 \mathrm{D}, 4 \mathrm{D}$ - degraded area plots

P, $2 \mathrm{P}, 3 \mathrm{P}, 4 \mathrm{P}$ - pine stand plots

Fig. 2. Research plots distribution on reclaimed Jeziórko sulfur mine area (part of Stale Forest District) 
Four replications in each category were chosen (identified by successive symbols: 1D, 2D etc., Fig. 2) for each of the plots initially selected during the fieldwork and belonging to the three specified categories: degraded (D), pine $(\mathrm{P})$ and birch $(\mathrm{B})$ tree stands. The centres of the plots were located on the central points of inoperative production boreholes.

\section{FIELD STUDIES}

Herbaceous vegetation coverage rates were determined on each stabilized plot using the Braun-Blanquet cover-abundance scale (Braun-Blanquet 1964). An inventory of trees was also completed. Tree species were identified and stand density was assessed, and measurements of diameter at breast height $(\mathrm{DBH})$ and tree height $(\mathrm{Ht})$ were taken on the plots. Tree vitality was determined according to the IUFRO classification adopted (Leibundgut 1958), using the standard designation scale: 10 for trees of vigorous growth, 20 for trees of normal growth, 30 for trees of declining growth. Eventually, each plot in the three categories distinguished (D, P, B) was sampled - five samples from $0-5 \mathrm{~cm}$ and 5-40 cm top layers of soil (in points distributed in accordance with the following scheme: one in the centre and 4 at a distance of $10 \mathrm{~m}$ from the centre in all cardinal directions). An auger was used to collect soil samples, after removing the existing organic horizon and litter. These samples were than used for producing mixed (collective) samples for specific layers, and each plot was examined.

\section{LABORATORY SOIL ANALYSIS}

Soil samples ( 24 in total, i.e. 3 site categories $\times 4$ replications $\times 2$ soil layers) were air dried and sieved $(2 \mathrm{~mm})$ in the laboratory. The following basic soil parameters were determined using soil laboratory procedures (Ostrowska et al. 1991, Van Reewijk 2002): particle size distribution (texture), using the Fritsch GmbH Laser Particle Sizer ANALYSETTE 22 (granulometric groups were described according to the Polish Soil Science Society, 2008); $\mathrm{pH}$, using the potentiometric method in $1 \mathrm{M} \mathrm{KCl}$ (1:2.5 soil-solution ratio); electrical conductivity (EC) was measured in the material dissolved in an aqueous solution (1:5) using a conductometer; soil organic carbon (SOC), total nitrogen
(TN), and total sulphur (TS) were measured using a LECO TruMac ${ }^{\oplus} \mathrm{CNS}$ analyzer, samples containing $\mathrm{CaCO}_{3}$ were washed (after an initial test with $\mathrm{HCl}$ ) in $10 \% \mathrm{HCl}$ to remove carbonates before SOC was determined; basic exchangeable cations $\left(\mathrm{Ca}^{2+}\right.$, $\mathrm{Mg}^{2+}, \mathrm{K}^{+}, \mathrm{Na}^{+}$) were extracted in $1 \mathrm{M} \mathrm{NH}_{4} \mathrm{Ac}$ on ICP-OES Thermo iCAP 6500 DUO Series spectrophotometer. Samples were mixed with a small portion of extractant and equilibrated. After 24 hours, suspensions were filtered, soils were washed with additional extractant and the total volume was refilled up to $100 \mathrm{~mL}$. Total exchangeable bases (TEB) were calculated as a sum of base cations $\left(\mathrm{Na}^{+}, \mathrm{K}^{+}, \mathrm{Ca}^{2+}, \mathrm{Mg}^{2+}\right)$. The exchangeable acidity of the soil samples $(40 \mathrm{~g})$ was measured using $1 \mathrm{~mol} \cdot \mathrm{L}^{-1}\left(\mathrm{CH}_{3} \mathrm{COO}\right)_{2} \mathrm{Ca}$ extraction, followed by potentiometric titration to $\mathrm{pH} 8.2$ with $0.1 \mathrm{~mol} \cdot \mathrm{L}^{-1}$ $\mathrm{NaOH}$. The exchangeable acidity $(\mathrm{Hh})$ was calculated from the amount of base used and expressed in $\mathrm{cmol}_{(+)} \cdot \mathrm{kg}^{-1}$. Cation exchange capacity (CEC) was defined as the equivalent sum of TEB and exchangeable acidity.

\section{RESULTS}

The following plots were defined using on-screen vectorization of an orthophotomap within the Stale Forest District, which covers the former Jeziórko sulphur mine area, in accordance with the land cover categories identified in this project: degraded plots (D) with a total area of 4.39 ha, plots with pine tree stands (P) occupying 40.89 ha, and plots with birch tree stands (B) occupying 115.69 ha.

Twenty of the twenty four samples covered by our study represented sandy soils (loose sandy soil, medium sand) according to the particle size distribution criteria defined in the PTG (Klasyfikacja uziarnienia gleb i utworów mineralnych 2008). The remaining samples were classified as sandy loam (Tab. 1).

The study soil samples were characterised by $\mathrm{pH}$ values from strongly acidic $\left(\mathrm{pH}\right.$ in $\mathrm{H}_{2} \mathrm{O}=2.1$, in $\mathrm{KCl}=2.0$ in the $\mathrm{D}$ category) to alkaline ( $\mathrm{pH}$ in $\mathrm{H}_{2} \mathrm{O}=7.27$ and in $\mathrm{KCl}=7.10$ in the $\mathrm{P}$ category) (Tab. 1). Plot category D included strongly and slightly acidic soils in the $0-5 \mathrm{~cm}$ and $5-40 \mathrm{~cm}$ layers. Categories with prevailing pine $(\mathrm{P})$ and birch (B) proportions in species composition of tree stands were covered by soils with slightly acidic $\mathrm{pH}$. 


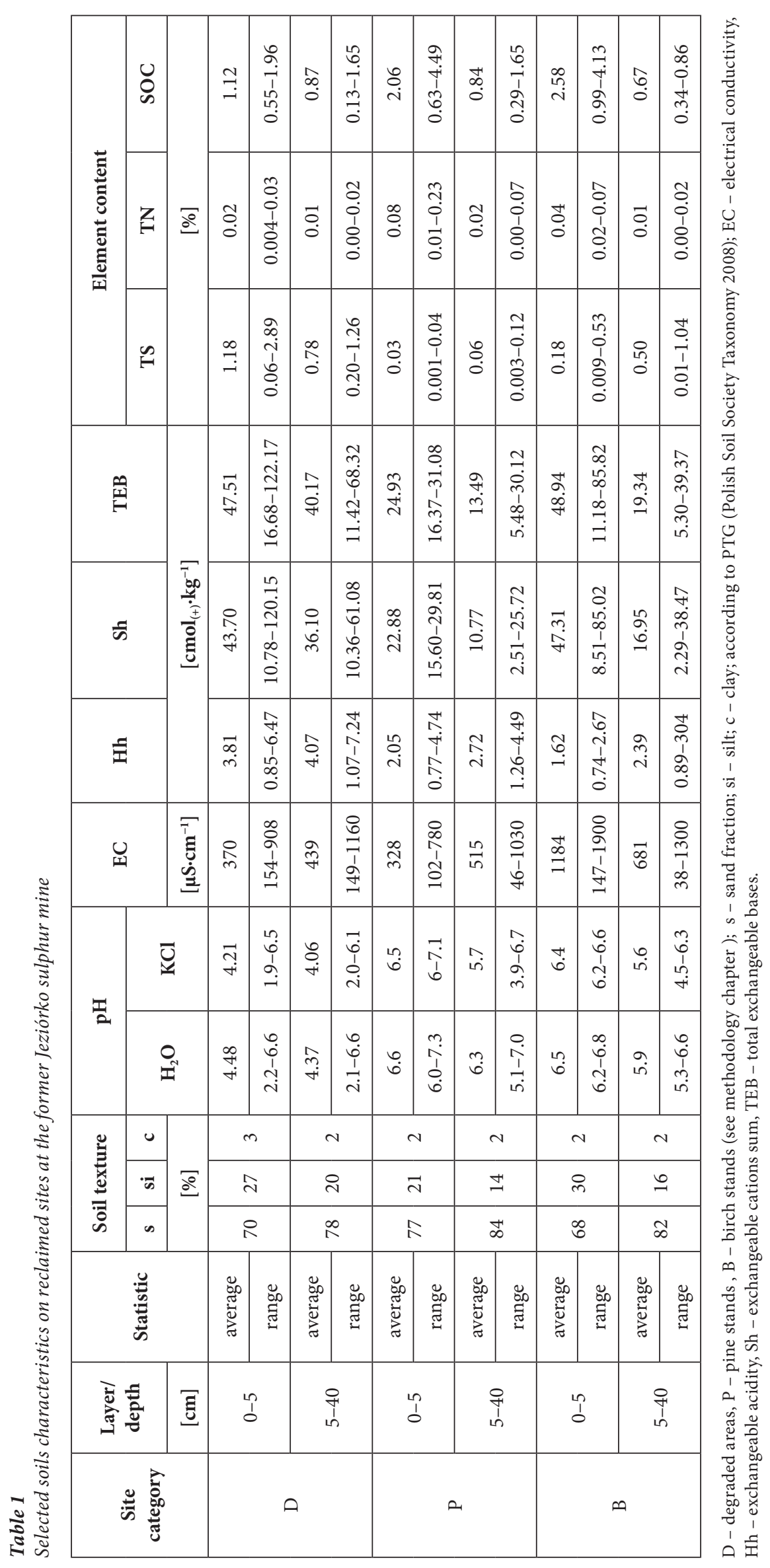


According to the extended classification for reclamation purposes (Krzaklewski et al. 1997), the soil samples from plot no. 4 in the D category showed extreme toxic acidity $(\mathrm{pH}<2.5)$, and the soil samples from plot no. 1 of the same category (1D) were characterised by highly toxic acidity ( $\mathrm{pH}$ 2.5-3.0)

Soil hydrolytic acidity $(\mathrm{Hh})$ in the D category showed an average of $3.30 \mathrm{cmol}_{(+)} \cdot \mathrm{kg}^{-1}$ of soil, and the highest values were observed in plot $4 \mathrm{D}$, i.e. $6.47 \mathrm{cmol}_{(+)} \cdot \mathrm{kg}^{-1}$ of soil in the $0-5 \mathrm{~cm}$ layer and $7.24 \mathrm{cmol}_{(+)} \cdot \mathrm{kg}^{-1}$ of soil in the $5-40 \mathrm{~cm}$ layer. In contrast, the lowest values were observed in plot $3 \mathrm{D}$, i.e. $0.85 \mathrm{cmol}_{(+)} \cdot \mathrm{kg}^{-1}$ of soil in the $0-5 \mathrm{~cm}$ layer and $1.07 \mathrm{cmol}_{(+)} \cdot \mathrm{kg}^{-1}$ of soil in the $5-40 \mathrm{~cm}$ layer. Category $\mathrm{P}$ showed $\mathrm{Hh}$ values averaging $2.39 \mathrm{cmol}_{(+)} \cdot \mathrm{kg}^{-1}$. The highest $\mathrm{Hh}$ values in this category were observed in plot 1P: $4.74 \mathrm{cmol}_{(+)} \cdot \mathrm{kg}^{-1}$ in the $0-5 \mathrm{~cm}$ layer and $4.49 \mathrm{cmol}_{(+)} \cdot \mathrm{kg}^{-1}$ in the 5-40 $\mathrm{cm}$ layer. The lowest $\mathrm{Hh}$ values in this category were observed in plot 3P: $0.77 \mathrm{cmol}_{(+)} \cdot \mathrm{kg}^{-1}$ in the $0-5 \mathrm{~cm}$ layer and $1.26 \mathrm{cmol}_{(+)} \cdot \mathrm{kg}^{-1}$ in the $5-40 \mathrm{~cm}$ layer. Average hydrolytic acidity reached $2.00 \mathrm{cmol}_{(+)} \cdot \mathrm{kg}^{-1}$ in category B. Hydrolytic acidity reached its highest values in plots $2 \mathrm{~B}$ and $3 \mathrm{~B}$ (ranging from 2.28 to $3.04 \mathrm{cmol}_{(+)} \cdot \mathrm{kg}^{-1}$ in the $0-5 \mathrm{~cm}$ and 5-40 cm layers, respectively) (Tab. 1). The lowest values were observed in plot $4 \mathrm{P}: 0.74 \mathrm{cmol}_{(+)} \cdot \mathrm{kg}^{-1}$ in the $0-5 \mathrm{~cm}$ layer and $0.89 \mathrm{cmol}_{(+)} \cdot \mathrm{kg}^{-1}$ in the $5-40 \mathrm{~cm}$ layer.

Category $\mathrm{D}$ plots showed $\mathrm{Ca}^{2+}$ cation values in soil samples that were higher than for the remaining plots and equalled $39.8 \mathrm{cmol}_{(+)} \cdot \mathrm{kg}^{-1}$ (Tab. 1). The lowest $\mathrm{Ca}^{2+}$ cation content was observed in category P plots $-16.6 \mathrm{cmol}_{(+)} \cdot \mathrm{kg}^{-1} \cdot \mathrm{Ca}^{2+}$ cation content in the birch (B) stand category was similar to that in category D soils and equalled $31.9 \mathrm{cmol}_{(+)} \cdot \mathrm{kg}^{-1}$. Contents of remaining exchangeable cations in soils were similar in all plot categories and amounted up to: $\mathrm{K}^{+}$ $0.02 \mathrm{cmol}_{(+)} \cdot \mathrm{kg}^{-1}, 0.04 \mathrm{cmol}_{(+)} \cdot \mathrm{kg}^{-1}, 0.04 \mathrm{cmol}_{(+)} \cdot \mathrm{kg}^{-1}$;

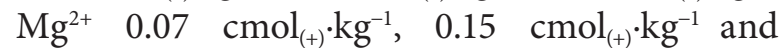
$0.14 \mathrm{cmol}_{(+)} \cdot \mathrm{kg}^{-1} ; \mathrm{Na}^{+} 0.02 \mathrm{cmol}_{(+)} \cdot \mathrm{kg}^{-1}, 0.01 \mathrm{cmol}_{(+)} \cdot \mathrm{kg}^{-1}$, $0.01 \mathrm{cmol}_{(+)} \cdot \mathrm{kg}^{-1}$ respectively for the $\mathrm{D}, \mathrm{B}$ and $\mathrm{P}$ categories.

The highest total content of exchangeable bases (TEB) occurred in category D plots in the $0-5 \mathrm{~cm}$ layer and reached $122.17 \mathrm{cmol}_{(+)} \cdot \mathrm{kg}^{-1}$ of soil (Tab. 1). The total exchangeable bases value in category $\mathrm{B}$ was also high and reached $85.81 \mathrm{cmol}_{(+)} \cdot \mathrm{kg}^{-1}$ of soil (1B in the $0-5 \mathrm{~cm}$ layer). Category $\mathrm{P}$ was characterised by the lowest TEB value, reaching a maximum of $31.08 \mathrm{cmol}_{(+)} \cdot \mathrm{kg}^{-1}$ of soil (plot $4 \mathrm{P}$ in the $0-5$ and $5-40 \mathrm{~cm}$ layers).

Electrical conductivity (EC) in category D ranged from 149 to $1160 \mu \mathrm{S} \cdot \mathrm{cm}^{-1}$, with an average of $405 \mu \mathrm{S} \cdot \mathrm{cm}^{-1}$. In the pine $(\mathrm{P})$ stand category EC, values fluctuated from $46 \mu \mathrm{S} \cdot \mathrm{cm}^{-1}$ to $1030 \mu \mathrm{S} \cdot \mathrm{cm}^{-1}$, with an average of $422 \mu \mathrm{S} \cdot \mathrm{cm}^{-1}$. In the birch (B) stand category, EC ranged from 38 to $1900 \mu \mathrm{S} \cdot \mathrm{cm}^{-1}$, with an average of $933 \mu \mathrm{S} \cdot \mathrm{cm}^{-1}$ (Tab. 1).

The highest total nitrogen (TN) content occurred in category P plots (an average of $0.05 \%$ ). The highest TN $(0.23 \%)$ and SOC (4.49\%) values were observed in plot $4 \mathrm{P}$ in the $0-5 \mathrm{~cm}$ layer. The highest SOC value was observed in B plots $(1.63 \%$ on average). Generally, category D plots were characterised by the lowest TN and SOC contents in soils. Total nitrogen contents (TN) in soils of this category fell within the range of $0.00 \%$ (below detection limit) to $0.03 \%$, while SOC ranged from $0.13 \%$ to $1.96 \%$ (Tab. 1 ).

Total soil sulphur (TS) in individual categories amounted on average: $980 \mathrm{mg} 100 \mathrm{~g} \mathrm{~g}^{-1}$ in the D category, $44 \mathrm{mg} \cdot 100 \mathrm{~g}^{-1}$ in the $\mathrm{P}$ category, and $342 \mathrm{mg}$. $100 \mathrm{~g}^{-1}$ in the B category (Tab. 1). In seven out of the eight plots initially classified as degraded (D), sulphur concentrations measured in accordance with IUNG guidelines (Kabata-Pendias et al. 1995) indicated high, i.e. IV degree contamination. Sulphur concentrations indicated third (III) degree, i.e. medium contamination, in only one plot $4 \mathrm{D}$ in the 0-5 cm layer). Among plots covered with birch (B) stands, IV degree, i.e. high sulphur contamination, occurred in two plots ( $1 \mathrm{~B}$ and $4 \mathrm{~B}$ in the $0-5 \mathrm{~cm}$ and 5-40 cm layers). II degree, i.e. concentration above natural level, occurred in one plot (2B in the $0-5 \mathrm{~cm}$ layer), and I degree, i.e. natural level, occurred in two plots $(2 \mathrm{~B}$, in the $5-40 \mathrm{~cm}$ layer; and $3 \mathrm{~B}$, in the $0-5 \mathrm{~cm}$ and $5-40 \mathrm{~cm}$ layers). Among plots covered with pine $(\mathrm{P})$ stands, only one plot (4P in the $5-40 \mathrm{~cm}$ layer) was characterised by IV degree, i.e. high contamination, one (2P in the 5-40 cm layer) by III degree, i.e. medium contamination; three plots (1P, $2 \mathrm{P}$ and $4 \mathrm{P}$, all in the $0-5 \mathrm{~cm}$ layer) showed II degree, i.e. increased concentrations, and two (1P in the 5-40 cm layer, $3 P$ in the $0-5 \mathrm{~cm}$ and $5-40 \mathrm{~cm}$ layers) were characterised by sulphur contamination of I degree, i.e. natural concentration.

A total of 32 herbaceous vegetation species were inventoried in all study plots. The highest percentage 
of herbaceous vegetation coverage (up to $85 \%$ ), as well as the highest biodiversity understood as the number of species identified (from 12 to 19), were characteristic of the birch (B) stands. The plots in pine $(\mathrm{P})$ stands showed lower rates of coverage (up to $75 \%$ ). The number of species ranged from 8 to 21 in this category (Tab. 2). The lowest coverage rates (from $1 \%$ to $50 \%$ ) and numbers of species (from 1 to 16) were characteristic of degraded plots (D).

Pine $(\mathrm{P})$ stands were characterised by a density of $\mathrm{N}=1457 \mathrm{pcs}^{-h^{-1}}$. In individual plots in this category, density varied from 1051 to 2133 pcs.ha ${ }^{-1}$. These stands were also characterised by the largest average diameter at breast height $(\mathrm{DBH})$ of $10.6 \mathrm{~cm}$, average height $(\mathrm{Ht})$ of $10.0 \mathrm{~m}$ and tree stand volume (V) of $0.93 \mathrm{~m}^{3} \cdot \mathrm{ar}^{-1}$ (Tab. 2). Birch (B) category stands were characterised by the highest density $\left(\mathrm{N}=1558 \mathrm{pcs}^{\mathrm{h}} \mathrm{ha}^{-1}\right.$; from $637 \mathrm{pcs}^{-h^{-1}}$ to 2038 pcs.ha $\left.{ }^{-1}\right)$; DBH amounting to $7.8 \mathrm{~cm}$ on average; Ht of $8.3 \mathrm{~m}$; and $\mathrm{V}$ of $0.50 \mathrm{~m}^{3} \cdot \mathrm{ar}^{-1}$ (Tab. 2). Plots in the degraded (D) microhabitat category were characterised by much lower and irregular density a mounting on average to $612 \mathrm{pcs} \cdot \mathrm{ha}^{-1}$ (from 238 pcs.ha ${ }^{-1}$ to 1090 pcs.ha $\left.{ }^{-1}\right)$; DBH of $7.7 \mathrm{~cm}$; Ht of $5.5 \mathrm{~m}$; and $\mathrm{V}$ of $0.06 \mathrm{~m}^{3} \cdot \mathrm{ar}^{-1}$ (Tab. 2).

Furthermore, the plots classified in category $\mathrm{D}$ were characterised by the highest proportion (53\%) of poorly developed trees, while typically developed trees numbered $40 \%$, and strongly developed trees a mere 7\%, according to the IUFRO classification. In category P plots, strongly devel- oped trees represent $25 \%$, typically developed trees $63 \%$, and poorly developed trees $12 \%$. On category B plots, strongly developed trees represent $9 \%$, typically developed trees $70 \%$, and poorly developed trees $21 \%$ (Tab. 2).

\section{DISCUSSION}

The exchange acidity values obtained indicated that category D soils were the most acidic, which was confirmed by $\mathrm{pH}$ at the lowest (acidic) values in this soil category.

According to the general Schachtschabel scale (Kowalik 2004), concentrations of specific exchangeable cations are beneficial for cultivated plant growth in the following ranges: $\mathrm{Na}^{+}$approximately $0.5 \mathrm{cmol}_{(+)} \cdot \mathrm{kg}^{-1} ; \mathrm{K}^{+} 0.5-1 \mathrm{cmol}_{(+)} \cdot \mathrm{kg}^{-1} ; \mathrm{Mg}^{2+}$ $2-3 \mathrm{cmol}_{(+)} \cdot \mathrm{kg}^{-1} ; \mathrm{Ca}^{2+} 12-17 \mathrm{cmol}_{(+)} \cdot \mathrm{kg}^{-1}$. According to the above division, proportions of specific exchangeable cations in the majority of soil samples from the study plots indicated $\mathrm{Ca}^{2+}$ cation concentrations to be close to favourable levels in terms of vegetation growth, whereas $\mathrm{Na}^{+}, \mathrm{K}^{+}, \mathrm{Mg}^{2+}$ cation concentrations might be considered to be too low in all study plots. However, it is worth noting, that vegetation typical of coniferous habitats grows very well in the poorest forest soils in terms of nutritional value, i.e. podzols, due to the tree stand self-feeding process and an efficient biological element cycle (Baule \& Fricker 1972, Puchalski \& Prusinkiewicz 1975).

Table 2

Selected characteristics of tree and vegetation on the reclaimed post-mine site of Jeziórko sulphur mine

\begin{tabular}{|c|c|c|c|c|c|c|c|c|c|c|}
\hline \multirow{3}{*}{$\begin{array}{c}\text { Site } \\
\text { category }\end{array}$} & \multirow{3}{*}{ Statistics } & \multirow{2}{*}{$\mathbf{N}$} & \multirow{2}{*}{ DBH } & \multirow{2}{*}{ Ht } & \multirow{2}{*}{ V } & \multicolumn{3}{|c|}{ IUFRO } & \multirow{2}{*}{$\begin{array}{c}\text { Number } \\
\text { of vascular } \\
\text { plant } \\
\text { species }\end{array}$} & \multirow{2}{*}{$\begin{array}{c}\text { Cover- } \\
\text { abundance } \\
\text { of vegetation }\end{array}$} \\
\hline & & & & & & 10 & 20 & 30 & & \\
\hline & & {$\left[\mathbf{p c s} \cdot \mathbf{h a}^{-1}\right]$} & {$[\mathrm{cm}]$} & {$[\mathbf{m}]$} & {$\left[\mathbf{m}^{3} \cdot \mathbf{a r}^{-1}\right]$} & \multicolumn{3}{|c|}{ [\%] } & [pcs/plot] & [\%] \\
\hline \multirow{2}{*}{ D } & average & 612 & 7.7 & 5.5 & 0.06 & \multirow{2}{*}{7} & \multirow{2}{*}{40} & \multirow{2}{*}{53} & 10 & 26 \\
\hline & range & $238-1090$ & $5.0-10.04$ & $3.61-6.88$ & $0.02-0.11$ & & & & $1-16$ & $1-55$ \\
\hline \multirow{2}{*}{$\mathrm{P}$} & average & 1457 & 10.6 & 10.0 & 0.93 & \multirow{2}{*}{25} & \multirow{2}{*}{63} & \multirow{2}{*}{12} & 14 & 35 \\
\hline & range & $1051-2133$ & $9.17-11.53$ & $9.54-10.63$ & $0.73-1.09$ & & & & $8-21$ & $3-75$ \\
\hline \multirow{2}{*}{ B } & average & 1558 & 7.8 & 8.3 & 0.50 & \multirow{2}{*}{9} & \multirow{2}{*}{70} & \multirow{2}{*}{21} & 14 & 74 \\
\hline & range & $637-2038$ & $5.68-8.89$ & $6.1-10.14$ & $6.4-11.35$ & & & & $12-19$ & $60-85$ \\
\hline
\end{tabular}

Explanations category in Table 1: N - number of stems per ha, DBH - average mean diameter at breast height, Ht - average height, V - stand volume; tree vitality according to IUFRO classification: 10 - trees of vigorous growth, 20 - trees of normal growth, 30 - trees of declining growth. 
Optimal total exchangeable bases (TEB) values for cultivated plant growth fall in between $15-20 \mathrm{cmol}_{(+)} \mathrm{kg}^{-1}$ (Kowalik 2004). Only 5 of the examined soil samples indicated total exchangeable bases within this range. The highest values occurred in category D plots (an average of $\left.43.84 \mathrm{cmol}_{(+)} \cdot \mathrm{kg}^{-1}\right)$. Equally high values occurred in the birch (B) stand category of plots, reaching an average of $34.14 \mathrm{cmol}_{(+)} \cdot \mathrm{kg}^{-1}$. The lowest TEB level was shown by pine (P) stand category of plots, reaching an average of $19.21 \mathrm{cmol}_{(+)} \cdot \mathrm{kg}^{-1}$.

Soil samples from (P) and (B) plot categories were generally characterised by neutral and alkaline $\mathrm{pH}$, which was the result of correctly completed neutralization using post-flotation lime, used for neutralization in phase one of the reclamation process at a dose of $300 \mathrm{Mg} \cdot \mathrm{ha}^{-1}$ (Długosiewicz 1999). Extremely toxic acidity was only observed in one plot of category D (pH below 2.5 in the $0-5$ and $5-40 \mathrm{~cm}$ layers), and highly toxic acidity ( $\mathrm{pH}$ 2.5-3.0) was determined for two plots: 1D (in the $0-5 \mathrm{~cm}$ and $5-40 \mathrm{~cm}$ layers), $4 \mathrm{D}$ (in the $0-5 \mathrm{~cm}$ layer). Both $\mathrm{pH}$ and hydrolytic acidity are soil acidity measures, and both these values indicate that the most acidic plots were to be found in category D.

Salinity measurements based on EC in the study plots showed values ranging from tolerable for vascular plants, i.e. $500 \mu \mathrm{S} \cdot \mathrm{cm}^{-1}$ (Gołda 2005), to harmful for most vascular plants (up to 2000 $\left.\mu \mathrm{S} \cdot \mathrm{cm}^{-1}\right)$. No plot indicated toxic salinity, i.e. above $2000 \mu \mathrm{S} \cdot \mathrm{cm}^{-1}$ (Tab. 1). The EC limit value for very sensitive plants is less than $1000 \mu \mathrm{S} \cdot \mathrm{cm}^{-1}$ (Gołda 2005). In the distinguished $D, P$ and $B$ categories, this value was exceeded in one sample from the 5-40 cm layer in category $\mathrm{D}$, in one sample from the same layer in category $\mathrm{P}$, and in five category $B$ samples (three from the $0-5 \mathrm{~cm}$ layer and two from the 5-40 cm layer). According to FAO recommendations for crop plants (Abrol et al. 1988) average salt content in soils on category $\mathrm{D}, \mathrm{P}$ and $\mathrm{B}$ plots indicated non saline $\left(0-2000 \mu \mathrm{S} \cdot \mathrm{cm}^{-1}\right)$. Such conditions may reduce sensitive plant yields. Soils on category B plots are close to slightly saline (i.e. with EC values close to $2000 \mu \mathrm{S} \cdot \mathrm{cm}^{-1}$ ) (Abrol et al. 1988). Yields of sensitive crops may be restricted in these conditions, i.e. with EC about $2000 \mu \mathrm{S} \cdot \mathrm{cm}^{-1}$. To summarize, it may be concluded that the EC obtained indicated medium or high salinity in most cases (plots 1D, 2D, 4D, 1P, 2P, 3P, 3B), and salinity that is harmful for sensitive plants in some cases (3D, 4P, 1B, 2B, 4B) (Gołda 2005). Howev$\mathrm{er}$, it is difficult to clearly determine the range of plant tolerance to salinity due to the multiple environmental factors that influence this capability in plants - not only climate, but also granulation of soil and soil moisture, as well as plant species characteristics including phase of growth, root reach, or adaptivity to existing conditions (Kozłowski 1997, Wilczek et al. 2012).

Low values of TN (average of $0.02 \%$ in the $0-5 \mathrm{~cm}$ layer and $0.01 \%$ in the $5-40 \mathrm{~cm}$ layer) and SOC (average of $1.12 \%$ in the $0-5 \mathrm{~cm}$ layer and 0.87 in the $5-40 \mathrm{~cm}$ layer) mainly occurred in category D plots. This resulted from low organic material accumulation with a lack of vegetation in these plots. Plots in the pine $(\mathrm{P})$ stand category were characterised by the highest TN concentrations in the $0-5 \mathrm{~cm}$ layer (an average of $0.08 \%$ ), and high SOC concentrations (an average of $2 \%$ in the $0-5 \mathrm{~cm}$ layer). The highest $\mathrm{SOC}$ contents were observed in birch (B) category plots that were also characterised by high TS levels. According to the IUNG criteria (Kabata-Pendias et al. 1995), which say that sulphur concentration exceeding $0.1 \%$ in surface soil layers is toxic (strong contamination), the soil samples covered by our study indicated strong contamination with this element. Total sulphur TS concentrations in 12 out of all study samples exceeded the permissible standards defined by the IUNG for agricultural soils (Kabata-Pendias et al. 1995), and also the values regarded by Skawina and others (1972) as toxic in sandy soils on reclaimed land (TS $>1.0 \%$ ). Seven samples collected from degraded (D) plots, four samples from plots with birch (B) dominance and one from pine (P) plots showed increased anthropogenic sulphur concentrations according to the IUNG scale (Kabata-Pendias et al. 1995).

Considering vegetation community characteristics (rates of plot area coverage and community species diversity) in individual plots, category $\mathrm{D}$ may be described as the most deprived (coverage from $1 \%$ to $50 \%, 10$ species on average), whereas the $\mathrm{B}$ and $\mathrm{P}$ categories of plots showed significantly higher percentages of coverage with herbaceous plants (from $60 \%$ to $85 \%$ on B category plots, from $3 \%$ to $75 \%$ on $\mathrm{P}$ category plots) and species diversity (an average of 14 species on B category and $\mathrm{P}$ category plots). 
Tree stand density and growth parameters, i.e. average $\mathrm{DBH}$, average $\mathrm{Ht}$ and average volume (V) in the categories of plots analysed indicated that the best growth parameters were achieved in pine $(\mathrm{P})$ category plots. The degraded (D) category plots were characterized by the poorest growth parameters. When interpreting the results of our study of tree stand and herbaceous vegetation characteristics, it is important to consider that the study was completed in a regular layout of circular plots which comprised contaminated points (the centres of study plots were located on former production boreholes, as far as possible), but also peripheral patches of forest stands where neutralization was correctly completed and vegetation succession was initiated. The inventoried trees located in category D plots mainly occurred in the border zone of the marked study plot, and tall vegetation did not exist in the places characterised by highest contaminations. This indicates highly diversified sulphur contamination levels across the entire study plot.

\section{CONCLUSIONS}

Plots initially categorized as degraded (D) showed high sulphur contamination, high salinity (EC), and strong acidity ( $\mathrm{pH}$ and $\mathrm{Hh}$ ) in topsoil layers $(0-5 \mathrm{~cm}$ and $5-40 \mathrm{~cm})$. The soil samples collected in these plots were also characterised by low nutrient contents. The unfavourable soil properties found in these plots caused significant retardation in plant growth or even forest decay, and continue to prevent efficient succession of vascular plants. These types of areas are examples of locally inefficiently completed reclamation, and specifically neutralization. Afforestation with pine and birch under the adverse conditions prevailing on former sulphur mining areas was successful in those locations where reclamation procedures, in particular flotation-lime neutralization at quantities of $300 \mathrm{Mg} \cdot h \mathrm{~h}^{-1}$, were correctly planned and completed. Generally, degraded plots covered an insignificant area of 4.39 ha, as compared to the hundreds of hectares of land reclaimed and transferred to forest management. Nevertheless they were interesting as the subject matter of microhabitat variability studies in the mosaic of restored ecosystems.
This study was financially supported by the Ministry of Science and Higher Education RP in frame of Statutory Financial Support (DS 3420, Department of Forest Reclamation and Ecology, University of Agriculture in Krakow, 2014) and BM (BM-4444, Research Founds for Young Scientist and Doctoral Students in 2015).

\section{REFERENCES}

Abrol, I.P., Yadav J.S.P. \& Massoud F.I., 1988. Salt-affected soils and their management. FAO Soil Bulletin, 39.

Baule H. \& Fricker C., 1973. Nawożenie drzew leśnych. Państwowe Wydawnictwo Rolnicze i Leśne, Warszawa.

Braun-Blanquet J., 1964. Pflanzensoziologie. Springer, Berlin, Wien, New York.

Długosiewicz F., 1999. Rekultywacja gruntów poprzemysłowych na terenie kopalni siarki „Jeziórko”. [in:] Górnictwo odkrywkowe - środowisko - rekultywacja, ze szczególnym uwzględnieniem KWB „Betchatów”: międzynarodowa konferencja naukowa, 8-9 czerwca 1999, Bełchatów, Kraków, 57-59.

Gołda T., 2005. Rekultywacja. Uczelniane Wydawnictwa Naukowo-Dydaktyczne AGH, Kraków.

Gołda T., Haładus A. \& Kulma R., 2005. Geosozologiczne skutki likwidacji kopalń siarki w rejonie Tarnobrzega. Inżynieria Środowiska, 10(1), 70-72.

Gąsiewicz A., Jasionowski M. \& Poberzhskyy A., 2012. Wpływ eksploatacji siarki na cechy geochemiczne środowiska powierzchniowego złóż siarki z pogranicza polsko-ukraińskiego. Biuletyn Państwowego Instytutu Geologicznego, 449, 5-40.

Härtel O., 1953. Eine neue Methode zur Erkennung von Raucheinwirkungen an Fichten. Zentralblatt Gesamte Forst Holzwirtschaft, 72, 12-21.

Kabata-Pendias A., Piotrowska M., Motowicka-Terelak T., Maliszewska-Kordybach B. Filipiak K., Krakowiak A. \& Pietruch C., 1995. Podstawy oceny chemicznego zanieczyszczenia gleb. Metale ciężkie, siarka $i$ WWA. Biblioteka Monitoringu Środowiska, PIOŚ, Warszawa.

Klasyfikacja gleb leśnych Polski, 2000, Centrum Informacyjne Lasów Państwowych, Warszawa.

Klasyfikacja uziarnienia gleb i utworów mineralnych: PTG 2008 [Polish Soil Taxonomy], 2008, Polskie Towarzystwo Gleboznawcze, Warszawa.

Kowalik S., 2004. Zagadnienia z gleboznawstwa. Uczelniane Wydawnictwa Naukowo-Dydaktyczne AGH, Kraków.

Kozłowski T., 1997. Responses of woody plants to flooding and salinity. Tree Physiology Monograph, Heron $\mathrm{Pu}-$ blishing, Victoria, Canada.

Krzaklewski W., Kowalik S. \& Wójcik J., 1997. Rekultywacja utworów toksycznie kwaśnych $w$ górnictwie węgla brunatnego. Monos, Kraków.

Leibundgut H., 1958. Beispiel einer Bestandesanalyse nach neuen Baumklassen. International Union of Forest Research Organisations. [in:] 12 ème Congrès, Oxford, 1956: rapports. 12th Congress: papers. 12. Kongress: Abhandlungen, Volume 2, Section 23 \& 24, London, 95-118. 
Menz F.C. \& Seip H.M., 2004. Acid rain in Europe and the United States: an update. Environmental Science and Policy, 7, 253-265.

Michno W., Dziedzic W. \& Czajkowski R., 2009. Przywracanie wartości użytkowych terenom górniczym na przykładzie KiZPS „Siarkopol”. [in:] XIII Warsztaty Górnicze z cyklu „Zagrożenia naturalne w górnictwie”, 17-19 czerwca 2009, Bogatynia - Świeradów-Zdrój, IGSMiE PAN, Kraków, 197-211.

Motowicka-Terelak T. \& Dudka S., 1991. Degradacja chemiczna gleb zanieczyszczonych siarka i jej wplyw na rośliny uprawne. Series: R - Instytut Uprawy, Nawożenia i Gleboznawstwa 284, Dział Wydawnictw Naukowych IUNG, Puławy.

Ostrowska S., Gawliński Z. \& Szczubiałka Z., 1991. Metody analizy $i$ oceny właściwości gleb i roślin: katalog. Dział Wydawnictw IOŚ, Warszawa.

Pawłowski S., Pawłowska K. \& Kubica B., 1985. Budowa geologiczna tarnobrzeskiego złoża siarki rodzimej. Prace Instytutu Geologicznego, 114, Wydawnictwa Geologiczne, Warszawa.

Pietrzykowski M., Krzaklewski W., Woś B. \& Pietrzak W., 2012. Ocena zagospodarowania leśnego zrekultywowanych terenów po otworowej eksploatacji siarki. Przeglad Górniczy, Miesięcznik Stowarzyszenia Inżynierów i Techników Górnictwa, 7(68), 98-103.

Plan Urządzenia Lasu dla Nadleśnictwa Nowa Dęba. Sporządzony na okres od 01.01.2003 do 31.12.2012 [Forest
Management of Nowa Dęba Forest Inspectorate for 20032012]. RDLP w Lublinie, BULiGL, Lublin.

Puchalski T. \& Prusinkiewicz Z., 1975. Ekologiczne podstawy siedliskoznawstwa leśnego. Państwowe Wydawnictwo Rolnicze i Leśne, Warszawa.

Skawina T., Trafas M. \& Gołda T., 1972. Problemy rekultywacji terenów pogórniczych Kopalni Siarki „Jeziórko”. Ochrona Terenów Górniczych, 20, 3-13.

Van Reewijk, L.P., 2002. Procedures for soil analysis. Series: Technical Paper 9, ISRIC, FAO, Wageningen.

Warmiński K., Rogalski L. \& Bęś A., 2005. Oddziaływanie dwutlenku siarki i siarczanów (IV) na zanik chlorofilu w niektórych roślinach wskaźnikowych. Zeszyty Problemowe Postępów Nauk Rolniczych, 505, 491-501.

Warzybok W., 2000. Rekultywacja terenów górniczych Kopalni Siarki "Jeziórko". [in:] Ochrona i rekultywacja gruntów: materiały konferencji naukowo-technicznej zorganizowanej wspólnie $z$ Instytutem Ochrony Środowiska, Przedsiębiorstwem Rekultywacji Terenów Górniczych „Jeziórko”, Baranów Sandomierski 14-16 czerwca 2000, Inżynieria Ekologiczna, 1, Ekoinżynieria, Lublin, 23-26.

Wilczek A., Skierucha W., Janik G., Cieśla J. \& Pichler V., 2012. Zasolenie gleby wyznaczane sensorami FDR działającymi w zmiennej częstotliwości. Woda-Środowisko-Obszary Wiejskie, 12, 2(38), 341-349.

Woś A., 1999. Klimat Polski. Wyd. PWN, Warszawa. 